\title{
The Difficult Legacy of Mining in Past and Contemporary Potosí and Ouro Preto
}

\author{
Andreza Aruska de Souza Santos \\ University of Oxford \\ Sue A. S. Iamamoto \\ Universidade Federal da Bahia
}

\begin{abstract}
The cities of Potosí (Bolivia) and Ouro Preto (Brazil) have played central economic roles during Latin America's long colonial history of mineral extraction, feeding the Spanish and Portuguese empires with silver (Potosí) and gold (Ouro Preto) and, consequently, changing the world's economy. Based on ethnography, interviews and archival research, in this article we argue that mining in these cities should be understood through the frame of a "difficult heritage" (Macdonald, 2009), incorporating mining's social and environmental atrocities in the official representations of their pasts. We first analyze how the colonial period was depicted in contemporary heritage policies and the role it played in fostering nationalism both in Bolivia and Brazil. Then, we explore how two main issues were excluded from the official narratives but remained represented in urban spaces and in local inhabitants' perceptions of them: the environmental impact directly or indirectly caused by mining and the racist violence imposed on African and indigenous peoples to guarantee mass labour for mining enterprises. Today, as contemporary Latin American societies are struggling to reinvent their national selves without
\end{abstract}

reproducing long-standing patterns of race inequalities and extractivism, accounting for the complexity of colonial mining heritage becomes increasingly relevant.

KeYwords: MINING, heritage, Potosí, Ouro Preto.

\section{RESUMO}

As cidades de Potosí (Bolívia) e Ouro Preto (Brasil) tiveram papéis econômicos centrais durante a longa história latino-americana de extração mineral, alimentando os impérios espanhol e português de prata (Potosí) e de ouro (Ouro Preto) e, consequentemente, mudando a economia mundial. Usando etnografia, entrevistas e pesquisa em arquivos, neste artigo, argumentamos que a mineração nestas cidades deve ser entendida através do conceito de "patrimônio difícil" (Macdonald, 2009), incorporando as atrocidades sociais e ambientais da mineração nas representações oficiais destes passados. Primeiro, analisamos como o período colonial apareceu nas políticas contemporâneas de patrimônio e como ele alimentou nacionalismos tanto na Bolívia quanto no Brasil. Em seguida, exploramos como duas questões principais foram excluí- 
das das narrativas oficiais, mas se mantiveram representadas nos espaços urbanos e nas percepções de habitantes locais sobre estes: os impactos ambientais direta ou indiretamente causados pela mineração; e a violência racista imposta a povos africanos e indígenas para garantir a mão-de-obra massiva da atividade mineradora. Hoje, enquanto as sociedades latino-americanas contemporâneas lutam para reinventar suas identidades nacionais sem reproduzir padrões persistentes de desigualdades raciais e de extrativismo, entender a complexidade da herança colonial da mineração se torna cada vez mais relevante.

PALAVRAS CHAVE: mineração colonial, patrimônio, Potosí, Ouro Preto.

\section{INTRODUCTION}

Environmental and social disasters are often part of the hidden past of great urban enclaves. In Latin America, no other cities better index the region's long-lasting contradiction of violent mineral extraction on the one hand, and of great artistic achievements on the other, than Potosí (Bolivia) and Ouro Preto (Brazil). Both cities were founded during colonial times and in their heydays sustained the Spanish and Portuguese empires with their apparently limitless supplies of silver and gold, thus changing the world's economy. Centuries of colonial and post-colonial mining in Potosí and Ouro Preto transformed the course of rivers, the height of mountains, and the direction of winds; they shaped the collective memories of their inhabitants; and they left behind a long line of social and environmental hazards.

This paper locates mining heritage in Potosí and Ouro Preto in time, the past and present mining in the two cities, as well as space, contextualizing the Baroque architectural legacy from colonial mines, Potosí and Ouro Preto are both UNESCO World Heritage sites and, at the same time, unsettling symbols of Bolivian and Brazilian national identities, requiring reinterpretations and renegotiations through the history of these countries. By looking at Potosí and Ouro Preto across centuries of mining history, we inquire how mining and cultural heritage co-exist in a contemporary scene. We analyze preserved buildings and entire cityscapes, while also discussing economic exclusion and environmental loss in those regions. From central buildings to the outskirts, this paper discusses how potosinos and ouropretanos have made sense of their cities' memories.

Potosí was established in 1545 to explore the silver ores of its mountain, Cerro Rico (Rich Mountain), and within a couple of decades became the largest city of the Americas with 160,000 inhabitants (Padden, 1975). It changed the world's economy by pouring enormous quantities of silver into the global market, representing around half of the world's silver production between 1575 and 1640 (Lane, 2019). By the time of Bolivia's independence in the early nineteenth century, Potosí had only 9,00o inhabitants, a tiny fraction of its former grandeur (Pentland, 1975). Ouro Preto, in turn, was founded at the end of the seventeenth century, a consequence of Brazilian and Portuguese hunt for gold in the inlands of Brazil. Mining in the region marked the gold cycle of Brazilian colonial 
economy and, at its peak in the beginning of the eighteenth century, more than 80,000 people lived in Ouro Preto (Maxwell, 1973). Gold extraction had declined by the mid eighteenth century, after less than fifty years of violent exploration. However, the city remained an important political center for the region, a role that was only challenged in 1897, when the capital of the state of Minas Gerais shifted to Belo Horizonte. By then, Ouro Preto's population was reduced to one fourth of its colonial size (De Souza Santos, 2019a).

Today, both cities have regained the population they had lost over the last century. According to the last Bolivian census in 2012, the city of Potosí has reached a population of 174,973 (INE, 2012), while Ouro Preto has 70,281 inhabitants according to Brazil's last census (IBGE, 2010), thus nearly reaching its former peak. Today, even though tourism is a part of both cities's economic activity and employs the local population, it is still mining that generates most local revenues.

In this paper, when discussing mining heritage in Potosí and Ouro Preto we move beyond the UNESCO criteria that look at architectural legacy. Instead, in the first section, we apply the concept of "difficult heritage" (Macdonald, 2009) to our cases to account for colonial mining's environmental and social atrocities. In the second section, we analyze how their colonial past appears in the cities' contemporary lives through urban landscapes, historical monuments, street names, and literature. When depicting official heritage policies in both cities, we discuss the role these cities played in fostering nationalism both in Bolivia and Brazil.
But there are also "subterranean memories" (Pollak, 1989), and we discuss environmental hazards and the violent oppressive labor imposed on racialized others (Indians and Africans) in colonial mining, and how these atrocities are echoed in contemporary Ouro Preto and Potosí. Across these sections, we defend the thesis that the absence of a more articulated memory of the negative impacts of colonial mining affects local identities and perspectives on the future.

This article is based on fieldwork conducted in Potosí and Ouro Preto during the authors' doctoral research, both carried out in 2013, and on subsequent visits thereafter. Because this work deals with social memories, an object of study that spans from the past to the present and can be studied among people and their relationships with certain objects and spaces, methodological strategies adopted here are multi-temporal and focused on both humans and materials.

In the case of Potosí, Sue Iamamoto interviewed sixteen activists from different working categories involved in regional mobilizations demanding local development measures from the national government. She focuses particularly on the nineteen days of civic strike in 2010, when the civic committee demanded the construction of roads, industrialization initiatives, and preservation measures regarding the Cerro Rico. Local newspaper archives and participant observations in public demonstrations and tours were also conducted. The aim of Iamamoto's research was to understand the relationship between social memories and collective action, or how the perception of past events and periods, such as the colonial experi- 
ence, informed the local civic movement. In order to comprehend material representations of social memories, urban spaces and landscapes were also investigated through touring the city and the mountain, observing people's interaction with these spaces and researching historical information about streets, buildings, monuments, and symbols.

In the case of Ouro Preto, Andreza de Souza Santos conducted a long-term ethnography, interviewing and observing the work of preservation authorities and affected residents, and visiting mining areas, archives, and tourism organizations. De Souza Santos lived in Ouro Preto for one year in 2013 and conducted over sixty semi-structured interviews besides engaging in participant observation. She lived first in a bed-and-breakfast, where she could take part in tours and understand the expectations of tourists in town. She also spent time with a family of tour guides as a guest in their house and developed a friendship with that group, who have an interpretative role in the city. Over that period of time, De Souza Santos participated in meetings held by the participatory council on the preservation of cultural heritage in Ouro Preto; in those meetings, she could analyze the difficult work of those dealing with the preservation of monuments that, more than just cementing a time, also immortalized aspects of segregation and exclusion. Analyzing the expectations, interpretations, and decisions taken over heritage, De Souza Santos' work discusses how the material heritage of Brazil's most iconic heritage site has been perceived, maintained, and contested.

The empirical material gathered in Potosí and Ouro Preto, presented in this paper, provides information on the importance of the colonial past for current residents in these cities. Metaphors recovered from the past that are used to represent present expectations and contradictions exemplify how the past is materially and symbolically present in these places. The empirical data from Ouro Preto and Potosí, despite emerging from different research projects, converges in presenting information about how politically and socially active inhabitants engage with heritage policies and the contradictions of historical experiences.

\section{THE DIFFICULT HERITAGE OF COLONIAL MINING}

In the last few decades, cultural heritage has become a recurrent theme in multiple fields including history, geography, social psychology, cultural studies, anthropology, sociology, and political science. From removing monuments or hailing places as sacred to claiming back museum objects in postcolonial encounters, the topic has reached a crescendo in a society that contests a past that often represents one narrative and does not take into account the different lenses through which dwellers see consecrated objects: gender, race, or economic variances (Collins, 2011; De Souza Santos, 2019a). On an individual level, forgetting or remembering actions from the past are questions that pertain to human relationships and to autobiographical accounts (Jovchelovitch, 2012). On a collective level, national governments have been at crossroads when deciding which stories are to be remembered, commemorated, or left unrepresented (Bodnar, 1992; Olick, 1998; 
Chuva, 2009) and how to include residents in these decisions if monuments are not be felled or vandalized (Brumann, 2009; Aykan, 2013; De Souza Santos, 2019b). This is not different in the case of Bolivia and Brazil. We look at national narratives in these countries and discuss how the past gained a material representation, or how materials gained a past through heritage: street naming, museums, monuments, and memorials. Understanding what is represented, however, also means seeing what is officially forgotten. It is necessary, thus, to focus on what is at the core of heritage-making concerns (positive accounts) and how national narratives dealt with environmental loss and slavery (difficult memories) in these two mining towns.

We discuss memories that emerge from the colonial mining experience in Ouro Preto and in Potosí using the concept of "difficult heritage," defined as a past "meaningful in the present" but "awkward for ... contemporary identity" (Macdonald, 2009, p. 1). In Macdonald's framework, originally thought to deal with the Nazi past in Germany, this heritage disturbs positive national identities and demands a reformulation of national selves through a public acknowledgement of perpetrated atrocities in order to prevent, through an "inoculation effect," the replication of similar atrocities in the future (Macdonald, 2015). This heritage paradigm is accompanied by a broader "memory boom" in the last decades of the twentieth century (Blight, 2009), in which national societies are required to "learn the lessons of history" and take responsibility for past actions such as genocides, wars, and dictatorships (Huyssen, 2003; Olick, 2007). However, applying the concept of difficult heritage to the representations of colonial mining pasts in Potosí and Ouro Preto requires some adaptation, since the negative impacts of mining experiences are not concentrated in specific years or decades as they are in the majority of social catastrophes of the twentieth century, but are distributed in the longue-durée of colonialism in Latin America (González Casanova, 1965; Quijano, 200o; Rivera Cusicanqui, 2010).

The first element that we focus on to discuss the difficult heritage of Latin American colonial mining is its profound ecological impact. The priority of environment emerges from recent disasters in Minas Gerais, in the cities of Mariana and Brumadinho, near Ouro Preto (Rezende \& Cordeiro, 2019). Both cities laid bare the paradox of mining having devastated landscapes and lives over the centuries yet remaining a sought-after activity. Little connection exists between previous environmental disasters and the present. Due to mineral exploitation, native forests were cut down, riverbeds were diverted, and soils were eroded or contaminated by mercury and other by-products of metal processing (Gligo \& Morello, 1980; Dean, 1997; Robins, 2011). The devastation of local ecologies went hand in hand with a process of subjugation and social disintegration of native peoples and the erasure of their systems of knowledge, which are deeply dependent on the management of territory (Gligo \& Morello, 1980; Machado Aráoz, 2014). Machado Aráoz (2014) depicts an image of combined genocide, ecocide, and epistemicide as the flip side of colonial mining, which represents "devastation as a principle" (p. 111). According to him, this 
principle orients contemporary extractivism in Latin America, a region that has experienced a commodities' boom cycle in the first decades of the twenty-first century (Svampa, 2013; Deonandan \& Dougherty, 2016). Latin American neo-extraction has expanded the role of the region in global extractive industry, horer this has generated local social and political conflicts, particularly involving indigenous and environmentalist groups resisting this role- (Bebbington, 2009; Dougherty, 2016). Remembering the destructive environmental aspects of mining cities is important because it helps societies to understand how current trends may mirror long-term patterns of global economy and ecology exploitation.

The second element we examine is the violence inflicted on native sroups, slaves, and their descendants to guarantee labor for the extractive industry. Fieldwork in Potosí and Ouro Preto reveals how socio-spatial segregation continues to be highly racialized. Understanding work relations in the past is thus important for addressing longterm inequalities. Work inside the mines was life-threatening, with frequent accidents and related diseases, and metal extraction only occurred because of a system of extreme violence. This violence was only tolerated because workers were the racialized Others, stripped of family or cultural identity and overseen by foremen. Race was a key category in the colonial system; it allowed the subjugation of indigenous and African people as if they were sub-human, thus creating subjective conditions for their extreme exploitation through regimes of enslavement and forced work (Quijano, 2005). Without their labour, the colonial enterprise would have been impossible. Contemporary Latin American societies are returning to this past to explain current patterns of long-lasting racism and violence. Opposing mid-twentieth century glorification of mestizaje and "racial democracy," indigenous and black movements in the last few decades have denounced the persistent effects of colonization and enslavement in the current inequalities of Latin American societies, and have demanded historical reparation policies such as affirmative actions, bilingual education, and the recognition of self-determination in autonomous territories (Albó, 1991; Wade, 1997; Guimarães, 2006).

Based on the ecological and social atrocities described above, we can begin to understand colonial mining memory as a difficult heritage. This understanding contests the necessity of mining activities amid environmental loss and the focus on miscegenation despite long-term inequality. It is no surprise that the official remembrance policies reproduced in contemporary Potosí and Ouro Preto prefer to focus on more positive aspects of their past experiences. Because it spanned centuries, colonial mining has left a material inheritance--creative arts, literature, architecture, industry--that local societies are proud of. Besides, both Potosí and Ouro Preto became important national symbols when Bolivia and Brazil became independent in the nineteenth century, in a process that interpreted past atrocities as exclusive to the colonial period, which would have been fully overcome in independent Latin American nations.

In what follows, we detail how people in Potosí and Ouro Preto relate to these memo- 
ries of the past, highlighting the complex relationship between the officially sanctioned representations of the past and the negative traces of colonial extractivism inhabiting popular imaginaries, the ones that represent a more difficult version of their national selves.

\section{CITIES AND THEIR MATERIAL PAST}

The relationship between memory and space reminds us that, just as actions happen in time and space, so does remembering. Since the ancient and medieval "method of loci," a memorizing practice in which individuals would store information in mental places (Carruthers, 1990; Connerton, 2009), imaginary or physical spaces have been identified as important mnemonic devices in which present generations share experiences with past ones. If memory is about content (stories, events, actors), the way it is reproduced depends on the human body and its habitual interaction with its surrounding environment (Connerton, 2009). Thus, everyday experience with the urban space is a central practice of memorialization, since it provides social relations with a "gestalt," giving them "order and focus" (Connerton, 2009, p. 24). In addition, the urban plan can have enduring characteristics (Connerton, 2009, p. 26). Potosí and Ouro Preto are examples of this endurance, with their colonial architecture and urban centers being made subjects of heritage protection. By protecting and maintaining their colonial appearance, these cities choose to enact and to directly relate with a certain period in their histories.

Ouro Preto was the first Brazilian cultural property included on UNESCO's list of world heritage sites, with its beautiful Baroque architecture distributed along irregular hills meeting UNESCO's first criterion to represent "a masterpiece of human creative genius," and the artistic innovation and syncretism of its churches and public monuments meeting the third criterion, to be an exceptional testimony of a specific cultural tradition (UNESCO a). Potosí was included later, in 1987, particularly because of its historical relevance and the display of a unique industrial complex from the sixteenth century that includes the Cerro Rico itself, along with Baroque religious buildings, a preserved colonial town with the Royal Mint, and the rancherias, the neighborhoods where indigenous workforce used to live (UNESCO b).

These protected legacies are seen when one visits the cities, with hills visible from every corner reminding the observer of centuries-long mining activities. In Potosí, the hill is the Cerro Rico, orange in color, while in Ouro Preto it is the Itacolomi, a mountain used as a landmark in colonial times to signal the place of the land of gold. In these towns' historical city centers and street signs carry former colonial names. In Potosí, signs are brownish orange-, a color originally made with pigments taken from the Cerro Rico that was used to paint houses. Such color has become popular in the last few decades: historical buildings have had their walls painted in orange and doors and balconies in green, replacing the republican fashion of white houses and brown doors and balconies (La Razón, 2003).

Efforts to recover colonial architectural 
heritage in the urban areas of Potosí date back to the 1940 and the celebration of the fourth centenary of the city, when the Society of Geography and History of Potosí proposed, among other measures, recovering old colonial names of streets and squares in order to promote "traditions and legends" related to the colonial city (Caro Martínez, 2011, p. 75). Recovering the names thus brings back a rich literature created by the city's chroniclers, whose main figure has been Bartolomé Arzáns de Orsúa y Vela, the author of Historia de la Villa Imperial de Potosí (1965), a thirteen-volume work left unfinished at his death in 1737. The legends, projected in the city streets, squares and churches, narrate stories of miracles, revenge, hidden treasures and impossible loves, recreating a time when Potosí was one of the wealthiest cities in the world. One of the most popular legends is about the treasure of Francisco da Rocha, who was arrested for forgery in the mid seventeenth century but had managed to hide his fortune of seven million pesos inside a cave at the outskirts of the city. The fortune has never been found by the authorities; even today, people still search for the Rocha treasure (Quesada, 1890; Omiste, 1992). The legends also remember a time of greed and violence, when gangs of Basques and Extremadurans fought against each other in the empedradillo (little cobbled square) (Lane, 2019). Colonial past also appears in Potosís very popular flag, inspired by a banner held by Francisco Pizarro given to Potosi in 1578, and taken to Bogotá after 1825 (Zavala Ayllón, 2012). The flag, also-inaugurated in the 1940s, has four white and red chequered squares, the colors of Castile and Léon.
Memories of colonial times are also materialized in Ouro Preto. When arriving in the city, one is greeted by eighteenth-century stories through neighborhood and street names. One of the city's entrances is in a neighborhood called Cabeças ("Heads"), which owes its name to the exhibition of decapitated heads during colonial times at that city entrance as a warning sign. Morro da Queimada, or The Hill That Burned, is a neighborhood where houses of those who quarreled with the crown about taxes were burned down. That event in 1720 marked not only a place but also a political transition because the prosperous Ouro Preto subsequently gained its own Governor who moved to town to better control incessant violence in the region (Zweig, 1942; Xavier, 2009). Not only neighborhoods but also streets carry with them the tales of the colonial era. Alvarenga Street, a pathway to the city center, is named after Mr. Alvarenga Peixoto, who was involved in the main Brazilian plot against the Portuguese Crown, Inconfidência Mineira (1789). He was later arrested and exiled to Angola in punishment for his participation in the failed rebellion (Xavier, 2009). There are other streets, corners and squares named after events that refer to positive memories: Flowers, Circus, and Carnival are words composing names of locations and reminding people of the happiness of Ouro Preto, and yet, it is violence that is often the lens through which one depicts the city. As we will show in the next section, the violence that inspires city naming in Ouro Preto is part of the national narrative that looked to Brazilian opposition to the Portuguese when preserving colonial architecture during the 
Republican years.

Common themes appear in the official heritage policies, materialized in the urban landscapes and monuments of both cities: a cult of local traditions and legends; the preservation of Baroque architecture in churches or institutional buildings; the appreciation of local colonial art, literature and industry; and a selective depiction of greed and violence that focuses its critique against colonizers.

\section{THE NATIONALIST RE-MAKING} OF A CITY

Retrospectively selecting historical events to justify the preservation of the city, in remembering the colonial past at the present time of independence and city depopulation, a dual challenge: national governments in Bolivia and Brazil looked for a narrative to re-signify these cities as spaces of nationalism and to make them once again attractive to tourists and businesses. Official heritage policies in Ouro Preto and Potosí were not simply celebratory of the colonial past. Negative aspects were often interpreted as a consequence of the colonial experience. In this view, Portuguese and Spanish colonial authorities were blamed and local elites appeared as defenders of national interests.

When preserving Ouro Preto, the sentiment of Brazilianness was invoked. Brazilian conspiracies against the Portuguese Crown gained centrality, with most landmarks named after the Inconfidência Mineira (1789) and events of colonial abuse that gave rise to that insurgency. This reinterpretation of the colonial town as a flashpoint for independence gained traction during
Getúlio Vargas' administration. In the 1930s, Vargas presidency overcame an oligarchic regime where landowners from Minas Gerais and São Paulo would take turns in politics (Fausto,1999). "National unit against regional forces" was a formula that consecrated his administration, requiring the creation of a national narrative that unfolded on several fronts: education, arts, cultural heritage, and cinema, to mention a few. In cultural heritage, most of the cities and monuments that are today preserved in Brazil gained protection at that time (Chuva, 2009). In the context of national unity, Baroque buildings in Ouro Preto and in other colonial towns were described by Vargas' memory-men (intellectuals in charge of cultural heritage) as expressions of the creativity of local architects and artists. The focus given to colonial buildings was that local architects and artists could build in the hinterlands of Brazil a European-style architecture with local materials. Thus, these colonial buildings would no longer be seen as the legacy of political and religious control by the former empire. (De Souza Santos, 2019a). The Inconfencineira was also reinterpreted through twentieth-century (and republican) eyes; it offered the idea of Brazilians resisting the colonizers, thus underplaying or nuancing inter-racial conflicts (De Souza Santos, 2019a). This version, of course, understates the fact that Mineira was an elite-led movement advancing their own tax interests. There was little action in favor of the majority of inhabitants. This was also a movement marked by betrayal, when the search for wealth meant both joining forces against the crown's tax system and denounc- 
ing other conspirators in exchange for one's own debt-forgiveness (Maxwell, 1973).

A national narrative for Potosí began as soon as Bolivia became a republic in 1825 . Simón Bolívar included the Cerro Rico in the first Bolivian Coat of Arms to symbolize the nation's wealth. Lately, scholars have identified in the historiography of Potosí, and particularly the work of Arzáns, the first attempt to imagine a "Creole nation," laying the groundwork for the emergence of Bolivian national subjectivity (García Pabón, 1998, p. 55). However, the city's most enduring contribution to the national imaginary is its representation as a trope for the plunder of natural resources by foreign powers, first the Spanish and later the British and North-Americans, a phenomenon that Dunkerley calls the "Potosí syndrome" (2007, p. 135). Today, activists from the local civic committee express this perspective through the metaphor of a "dairy cow": "All the people say: Potosí is the permanent dairy cow, which generates milk, but the Potosino people don't make use of it. So, this is a vision we have had for a long time." In this view, Potosís resources sustained Bolivia and, before that, Spain: "We cannot be forgotten, since a lot of wealth was taken from the insides of our mountain, not only to Bolivians, but also to Latin America and Europe. Our wealth [...] strengthened many countries there in the old world." ${ }^{2}$ Thus, Potosís historical example feeds Bolivian economic nationalism, the idea that local natural resources should be used to industrialize and develop the region, which can be traced back to the nationalist governments of the 1930s, the first to nationalize hydrocarbons in the country's history.
Even though the official representations of these cities vary in their main contents, they are both intimately connected to the history of Latin American nationalism in the twentieth century. Nation-making on the continent was predominantly a task of the national populist governments of the mid-twentieth century and faced the challenges of creating unifying national symbols and promoting economic independence. Glorifying the development agenda, these governments did not perceive the environmental degradation due to colonial mining as a problem that needed to be addressed.

\section{ENVIRONMENTAL DISASTERS, CONTAMINATION, AND DEPOPULATION}

Although the environmental dimension of colonial mining is often absent from national preservation narratives, it does appear in the popular imaginary in Potosí and Ouro Preto. This section thus focuses on long-lasting ecological impacts of mining and how local populations express them while considering the cities' economic viability and natural disasters.

Potosí has suffered from a number of ecological catastrophes over the centuries. Since 1545 , around 45,000 metric tons of mercury been released into Potosís environment, leaving a legacy of persistent soil contamination that extends to the present day (Robins, 2011). In 1626, a major flood caused by the failure of Caricari dam, which provided water for the ore-grinding mills (ingenios) spread along the Ribera canal, killed more than 2,0oo people and destroyed 
hundreds of houses (Gioda et al., 1998). Today, it is the Cerro Rico itself that runs the risk of collapse, since its structure, described by Potosinos as "Swiss cheese," is damaged. In the past decade, new craters were found at the top of the mountain (El Potosí, 2010), which has lost around 200 meters of its original height (Cambio, 2009). Because of these damages, UNESCO included Potosí on its list of endangered heritage sites in 2014 (UNESCO, 2014). Local inhabitants fear that the collapse of the mountain would condemn the city to disappearance:

Now about the Cerro Rico, I'd like people to take note. The Cerro Rico is falling down-it has already been filled with car tires. Whatever the government says, it does nothing. They keep making the mountain work [siguen haciendo trabajar la montaña]. Tomorrow or the day after, the Cerro Rico might crumble and will disappear. We must keep this as a relic, because Potosí is our very own tourist attraction. If it crumbles, we'll no longer have a single... Nothing for tourism, we'll have nothing; all will die. (Anonymous, interview on September 25, 2013)

This testimony expresses a very common issue among local inhabitants, both in Ouro Preto and Potosí: the fear that, after the exhaustion of natural resources, the city will become an empty "mining camp." Depopulation is both a fear of what is about to come and a memory. Ouro Preto faced a population exodus in the early twentieth century, when it had only a fraction of its former colo- nial-era population. A common saying is that "people shut the door with the keys inside," for they were never to return. Most residents moved to the new capital Belo Horizonte upon its inauguration (1897), leaving behind a city that had no future. Nowadays, the registry of houses in Ouro Preto is still compromised as houses previously abandoned have contested ownership.

In Brazil, gold mining in the Minas Gerais region depended on dredging river beds, diverting streams, washing over hillsides and overturning soils (Dean, 1997). These activities deeply affected local environments, altering rivers (which became muddy) and contributing to the deforestation of the Atlantic Forest. Dean (1997) calculates that around 4,000 square meters of soil were overturned by gold mining in the eighteenth century. Narratives about gold extraction in Ouro Preto usually focus on famine, as the city produced gold, not food. Oral stories in the region narrate a town where explorers did not want to invest in less profitable activities such as cattle farming or agriculture, and while searching for gold some died of hunger. Deaths that occurred during the search for ore are also related to slavery and lethal working conditions, as we show in the next section.

Today, landslides are one of the most serious ecological concerns among local residents. More recent industrial activities in Ouro Preto have led to the peripheral expansion of the city, which, already preserved as a heritage site, cannot accommodate temporary workers in its main area. While in colonial times wealth and poverty were expressed inside the houses, with house owners, domestic workers and slaves each 
occupying different areas of the house (Gledhill, 2013), nowadays such separation takes place in different sectors of the city, with the poor living on the slopes of hills. Such irregular occupation not only threatens the preservation of the city, as houses are visible from preserved areas, but also the lives of residents (UNESCO 1990, 1993, 2003, 2004). Ouro Preto has a history of severe rainfall and landslides (Prefeitura Municipal de Ouro Preto, 2012), with deaths caused by mudslides suffocating residents or passersby below hills. In addition, dam disasters in Minas Gerais, in Mariana (12 kilometers away from Ouro Preto) in 2015 and in Brumadinho (113 kilometers away from Ouro Preto) in 2019, called attention to the devastating effects of mining in the region.

\section{RACE, LABOR, AND VIOLENCE}

Environmental exhaustion, however, is not the only unresolved legacy of mining that haunts contemporary inhabitants of Ouro Preto and Potosí. Mining in colonial times was dependent on dangerous, $\boldsymbol{x}_{\boldsymbol{\Lambda}}$ cheap and mass labour, mainly achieved through forced work and enslavement of indigenous groups and Africans, the racialized Others that were considered more suitable for colonial work exploitation.

In Ouro Preto, the memory of slavery is spatially localized. Inside old mines, where previously enslaved populations worked, their descendants are nowadays tour guides. In tours, as I detailed elsewhere, the history of slavery is recounted through spiritual and embodied narratives (De Souza Santos, 2019a). It is embodied as visitors are invited to squat in claustrophobic tunnels while a guide replicates the noise of work materials and narrates how black slaves used to work in the past. It is spiritual because former slaves are said to have the ownership of the place, and their spirits can deny entrance to the mine by making a visitor fall or hit their heads against the walls (De Souza Santos, 2019a). It is not uncommon that a violent past gains ghostly explanations (Ulturgasheva, 2017). In the case of Ouro Preto, however, this means that mining territories are not always inviting to local residents, who may fear such spaces. It is common in town to hear stories of ghosts, spirits, and voices, and the world of the dead is alive in local narratives. People in Ouro Preto often refer to the slavery in the city's past when talking about dreams or nightmares as well as moments of loss or fortune. Though slavery is gone, its "energy" remains.

A more convenient encounter slavery is positive, such when miscegenation and the emergence of the mulatto through education is addressed. Aleijadinho, a Brazilian sculptor who was the son of a Portuguese architect and a Brazilian slave, is a key character in such Having sculpted the interior of Baroque churches, that artist also expressed a local way of engaging with slavery, complicating the idea of exploitation and giving Minas Gerais' society of the past a representation that included a category of artisans in addition to slaves. Even though stories of aspiration and ascension are not enough to deny a past of torture, low life expectancy, abuse and slavery, Baroque churches are more visited than mines. The history of slavery thus remains under-rep- 
resented and mainly told through torture objects--in local museums (Hale, 1997) and in the interior of mines--attended by few visitors (De Souza Santos, 2019a). Gurrent mining, on the other hand, takes place in districts far away from the protected perimeter of the city, locations with low population density where workers mainly commute from neighboring towns (De Souza Santos, 2019b).

In Potosí, after the first decades of bonanza, when some independent Indians thrived thanks to silver extraction and refining (Lane, 2019), the reforms carried out by Viceroy Toledo put in place the mita, a system of forced labor inspired by an old Inca practice, as a keystone of silver production. In order to increase and consolidate the workforce, the mita recruited every year one seventh of the adult male population in every community to work in the mines. Even though the work was paid, daily wages were extremely inferior to free market prices and were not enough to cover the basic needs of mitayos and their families (Lane, 2019). There were also free workers in the mine, the mingas, but the most intense and dangerous activities were undertaken by mitayos (Padden, 1975). In 1572, the first Toledan mita mobilised 9,500 men along with their respective families from 16 highland provinces (Mangan, 2005). Once in Potosí, the families settled in indigenous neighborhoods, the rancherías, mostly located south of the city center, beyond the Ribera canal and between the city and the Cerro Rico. Each ranchería congregated mitayos from the same provinces and communities, who also had specific churches assigned to them (Querajazu, 2010).
Enslaved Africans also contributed to the city's workforce but worked mainly outside the mines as blacksmiths, in the Royal Mint, and in domestic services (Lane, 2019). The Toledan reforms, which also included technical innovations such as the system of dams and mercury amalgamation, provided the conditions for a more intensive exploitation of silver and, in the following decades, Potosí reached its golden age (Lane, 2019).

The precarious working conditions in the mines were denounced when friar Domingo de Santo Tomás called the mines "a mouth of hell” in 1550 (Lane, 2019). Some decades later, Luis Capoche described the mines as a "fierce beast" that indigenous workers alive, through cave-ins and diseases related to dust inhalation. The long journeys mitayos had to take to reach Potosí were also criticized for its harsh conditions and all sorts of abuses to which Indian families were subject (Lane, 2019). Today, it is a popular saying in Bolivia that two bridges could be built between Potosí and Spain with the outcome of its mining: one with the silver, the other with the bones of the mitayos (Céspedes, 1974).

Since Potosí is still a mining city, the memory of the abuses suffered by mitayos is still cultivated among present-day mine workers in the mountain. The image of the mitayos and their terrible working conditions is the "historical matrix" of the miners' discourse on the sacrifices made inside the mine (Absi, 2005). Miners today pay tribute to those who have died inside (Absi, 2005). Work inside the mine is extremely ritualized, where protecting saints create bonds between current miners and the 
generations of miners who were doing the same activities in past centuries (Nash, 1979; Taussig, 1980; Absi, 2005; Scott, 2008).

In Potosí and Ouro Preto, the inherited colonial racism is also perceived outside the mines through segregation in housing areas. In Potosí, the line following the Ribera gulch between the Spanish city center and the the rancherías used to separate the city's inhabitants racially. Today, this line divides middleclass and mine-worker neighborhoods, the latter being in the areas of former rancherías. As Absi (2005, p. 66) points out, "Colonial urbanisation established borders between the city's inhabitants: miners rarely come to the city center, which is considered a space of the 'city's good society and its golden youth." In Ouro Preto, segregation is perceived in a division between center (wealthy residents and tourists) and a periphery (the majority of residents). A contradiction in the case of Ouro Preto is that the permanent, preserved city houses mainly temporary residents (tourists and students), while permanent residents live in improvised and temporary houses in informal neighborhoods.

\section{CONTEMPORARY MINING AND HERITAGE}

Both Potosí and Ouro Preto are still mining towns in which extractive industry has increased in the past decades driven by the commodities' boom in Latin America (Svampa, 2013; Dougherty, 2016). Though these cities developed alternative economic resources, such as education (Ouro Preto is home to a large university), tourism (both cities attract a large number of tourists each year), and local administration (Potosí is a departmental capital and Ouro Preto's local government is a coveted working space), it is mining that has been generating ty of lopened in colonial times, contemporary mining continues to threaten the environment of these cities. Complaints about dirty water in one of Ouro Preto's key mining districts, Miguel Burnier, abounded in 2013 (De Souza Santos, 2019b). In Potosí, besides the endangered situation of the Cerro Rico, which is still being exploited, the Pilcomayo River, which flows into La Plata River, suffers with intense contamination from mining activities (Oieni, 2018).

Current workforce of the mining industries has different features in both cities. While in Ouro Preto mining employs a low number of residents and the industry is no longer as labor intensive as in the past, in Potosí mining is still a key job provider. In terms of mining's participation in the city economy, four in ten workers in Potosí today are directly dependent on mining (Ferrufino Goitia, Eróstegui Torres, \& Gavincha Lima, 2011), while 12.7 percent of the economically active population work in the extractive sector of mining and hydrocarbons (INE, 2012). In both places, however, workers face dangerous working conditions, with frequent small- and large-scale accidents, from the repeated cave-ins in Potosí to the dam failures in Mariana and Brumadinho that put the entire region on constant alert. In Potosí, the life-expectancy of a miner is just 40 years due to silicosis, a disease that develops from breathing in silica dust (Moh, 2014). Other difficulties in both cities relate to the unpredictability of the jobs given the export-led 
nature of the production, which means that mining licenses are short-term while environmental devastation and migration affect cities and people on a long-term basis.

Faced with the continuous negative impacts of mining, one might ask why local societies in Ouro Preto and Potosí still support this industry. As A. Bebbington, Hinojosa, D. Bebbington, Burneo, and Warnaars (2008) have stated, the defense of the mining industry by local population seems "Faustian in extreme" (p. 888), but it expresses a pact, even if it is a pact with uneven benefits: without other economic activity to satisfactorily replace mining, they will resort to mining to guarantee the city's-income and jobs. However, this Faustian pact cannot be entirely understood in terms of economic evaluations of costs and benefits. Literature on social movements suggests that motivations for action depend on cultural understandings of oneself, identities, and how social actors project expectations (Melucci, 1988). While in Ouro Preto tourism employs many residents, it is the prospect of working for large mining companies that dazzles. The following statement, given by an experienced radio journalist in Potosí, illustrates this argument about the relation between local aspiration and mineral extraction:

The miner is the protagonist of our economy, history and everything related to the society Potosí has, even art... Without the Potosino miner we cannot understand the history of Potosí, as we cannot understand the history of Bolivia without Potosí. So the moun- tain is a sort of a curse for us, we are and will always be miners.... Today it is very trendy to protect the environment, to complain about contamination. This demonizes mining activities, but we cannot live without them. On what are we going to live? (Omar Velazco, interview on November 7,2013$)$

We understand Velazco's testimony as an indication of identity elements ("we are and will always be miners") limiting the imagination of alternatives to mining in a contemporary context, both in Potosí and Ouro Preto. The "resource curse," used by Auty (1993) to account for the deadlocks caused by enclave economies, is expressed here as a sort of ontological condition of mining cities, a destiny that cannot be diverted. This mining identity is fed by colonial mining heritage policies, which glorify the colonial past and turn its social and ecological atrocities into something unavoidable.

The paradox in Potosí and Ouro Preto is that tourism and heritage preservation have been claimed as possible substitutes for mining as main economic activities in these cities. However, in contrast to what happens with natural heritage, the cultural heritage of Potosí and Ouro Preto reinforces the extractive industry Both $_{2}$ in terms of content and in terms of finance, preservation activities are sponsored by mining. With patrimony profiting from mining and nuancing its "difficult" legacies, there is a system of perpetuity where new mining sustains old buildings, which in turn tell a positive story of mining (De Souza Santos, 2019b). Thus, to understand colonial mining as a difficult heri- 
tage, as we propose in this article, offers a way out of this labyrinth.

\section{CONCLUSION}

While investigating Ouro Preto and Potosís colonial mining pasts, we applied the concept of "difficult heritage" (Macdonald, 2015) in a Latin American context. As argued in the first section of this article, Latin American societies are marked by long-term impacts of atrocities brought by the colonial experience. Colonialism inaugurated a resource extraction pattern in the region that persists in the present and that has devastated local eco-systems and divided society racially, socially and spatially. However, gold and silver mines have also prompted the formation of monumental towns and artistic expressions, thus complicating the use of Macdonald's term.

Heritage policies in Potosí and Ouro Preto have focused on the positive image of these cities. Although past injustices are indirectly represented in local stories and through spatial segregation, these "subterranean memories" are not enough to promote a local identity that clearly rejects extraction projects with high environmental and social impacts. The "difficult" legacies of these cities need to gain voice to challenge persistent injustices. Memories of Potosí and Ouro Preto discussed in this article encompass representations that are able to deal with the complexity of the colonial experience. This does not mean blurring the lines between perpetrators and victims, as Macdonald (2015) has criticized recent "difficult heritage" initiatives in Europe, but actually to include the dimension of oppression as constitutive of cultural heritage.

Contemporary societies in Brazil, Bolivia and beyond have new challenges regarding their past, present and future. Racial inequalities, mining disasters, water contamination, mining-extractive vocation, and the role of indigenous peoples in forging colonial-and later national-economy are all topics that remain under-represented in national celebrations, monuments, or commemorations. We claim that, while the past is imagined in its selective frame, the present and future of these towns remain selective, perpetuating race inequalities, urban segregation,-social inequality and the devastation of forests and species. A more inclusive society will be one that allows more people to imagine and more narratives to be imagined in the colonial stages that Potosí and Ouro Preto have framed.

\section{ACKNOWLEDGEMENTS}

We would like to thank Mara Duer and Simone Vegliò, organizers of the workshop Modern Colonial Geographies in Latin American, and the comments and suggestions made by Alexander Mielke and the journal's anonymous reviewers. Sue Iamamoto's research was conducted in Queen Mary University of London, under the supervision of James Dunkerley, and was funded by Capes Foundation, Brazil (BEX 0557/129). Andreza de Souza Santos' research was funded by the Scottish Funding Council, the University of St Andrews, and the Russell Trust Award. 


\section{NOTES}

1 Benigno Castillo, executive secretary of the press workers union (interview on September 11, 2013). A leader of the neighborhood movement (interview on September 25, 2015) and Emilio Elias (interview on September 25, 2013) also defined the department as a "dairy cow."

2 Emilio Elias, member of the teachers' union (interview on September 25, 2013).

\section{REFERENCES}

Absi, P. (2005). Los ministros del diablo. El trabajo y sus representaciones en las minas de Potosí. La Paz: PIEB; IRD; IFEA; Embajada de Francia.

Albó, X. (1991). El retorno del indio. Revista Andina, 9(2), 299-331.

Arzáns de Orsúa y Vela, B. (1965). Historia de la Villa Imperial de Potosí. Volumes I and II. L. Hanke \& G. Mendoza (Eds.). Providence: Brown University Press.

Auty, R. M. (1993). Sustaining development in mineral economies: The resource curse thesis. London and New York: Routledge.

Aykan, B. (2013). How participatory is participatory heritage management? The politics of safeguarding the Alevi Semah ritual as intangible heritage. International Journal of Cultural Property, 20(4), 381-405.

Bebbington, A., Hinojosa, L., Bebbington, D. H., Burneo, M. L., \& Warnaars, X. (2008). Contention and Ambiguity: Mining and the Possibilities of Development. Development and Change, 39(6), 887-914.

Bebbington, A. (2009). The New Extraction. Rewriting the Political Ecology of the Andes? NACLA Report on the Americas, 42(5), 12-20.

Blight, D. W. (2009). The Memory Boom: Why and Why Now? In P. Boyer \& J. V. Wertsch (Eds.). Memory in Mind and Culture (pp. 238-251). New York: Cambridge University Press.

Bodnar, J. (1992). Remaking America: Public Memory, Commemoration, and Patriotism in the Twentieth Century. Princeton: Princeton University Press.

Brumann, C. (2009). Outside the glass case: the social life of urban heritage in Kyoto. American Ethnologist, 36(2), 276-299. 
Cambio (2009). El "Sumaj Orcko" ha perdido 200 metros de su "magnífico cerro puntiagudo." Cambio, 7 Días, Revista de Domingo, 8-11.

Caro Martínez, M. (2011). Potosí Ille Factum. Potosí.

Carruthers, M. (1990). The book of memory. A study of memory in medieval culture. Cambridge: Cambridge University Press.

Céspedes, A. (1974). Metal del diablo. Buenos Aires: Editorial Universitaria de Buenos Aires.

Collins, J. (2011). Melted gold and national bodies: The hermeneutics of depth and the value of history in Brazilian racial politics. American Ethnologist, 38(4), 683-70o.

Connerton, P. (2009). How modernity forgets. Cambridge: Cambridge University Press.

Chuva, M. (2009). Os Arquitetos da memoria: Sociogênese das práticas de preservação do patrimônio cultural no Brasil (anos 1930 - 1940). Rio de Janeiro: Editora UFRJ.

De Souza Santos, A. A. (2019a, forthcoming). The Politics of in Brazil. London: Rowman \& Littlefield International.

De Souza Santos, A. A. (2019b). Trading time and space: Grassroots negotiations in a Brazilian mining district. Forthcoming in Ethnography,

Dean, W. (1997). With Broadax and Firebrand: The Destruction of the Brazilian Atlantic Forest. Berkeley and Los Angeles, CA: University of California Press.

Deonandan, K., \& Dougherty, M. L. (2016). Mining in Latin America: Critical Approaches to the New Extraction. New York, NY: Routledge

Dougherty, M. L. (2016). From global peripheries to earth's core. The new extraction in Latin America. In K. Deonandan \& M. L. Dougherty (Eds.), Mining in Latin America: Critical Approaches to the New Extraction (pp. 3-24). New York, NY: Routledge.

Dunkerley, J. (2007). Evo Morales, the "Two Bolivias" and the Third Bolivian Revolution. Journal of Latin American Studies, 39( 01), 133-166.

El Potosí (2010, June 25). Asambleísta denuncia nuevo hundimiento en el Cerro Rico. El Potosí, p. 3. 
Fausto, B. (1999). A concise history of Brazil. Cambridge: Cambridge Univ. Press.

Ferrufino Goitia, R., Eróstegui Torres, R., \& Gavincha Lima, M. (2011). Potosí: El cerro nuestro de cada día. Relevancia económica en la región y la ciudad capital. La Paz: Labor.

García Pabón, L. (1998). La patria íntima. Alegorías nacionales en la literatura y en el cine de Bolivia. La Paz: Plural; CESU-UMSS.

Gioda, A., Serrano, C., \& Frey, M. (1998). L'eau et l'argent à Potosi. Houille Blanche, (7), 65-75.

Gledhill, J. (2013). Redeeming the Promise of Inclusion in the Neo-Liberal City: Grassroots Contention in Salvador, Bahia, Brazil. In S. Abram \& G. Weszkalnys (Eds.). Elusive Promises: Planning in the Contemporary World, (pp. 117-136). New York: Berghahn Books.

Gligo, N., \& Morello, J. (1980). Notas sobre la historia ecológica de América Latina. Estudios internacionales, $13(49), 112-148$.

González Casanova, P. (1965). Internal Colonialism and National Development. Studies in Comparative International Development, 1(4), 27-37.

Guimarães, A. S. A. (2006). Depois da democracia racial. Tempo Social, 18(2), 269-287.

Hale, L. L. (1997). Preto velho: resistance, redemption, and engendered representations of slavery in a Brazilian possession-trance religion. American ethnologist, 24(2), 392-414.

Huyssen, A. (2003). Present Pasts. Urban Palimpsests and the Politics of Memory. Stanford, CA: Stanford University Press.

Instituto Brasileiro de Geografia e Estatística (IBGE) (2019). Cidades: Ouro Preto. Retrieved from: https://cidades.ibge.gov.br/brasil/mg/ouro-preto/panorama.

Instituto Nacional de Estadística (INE) (2012). Censo Nacional de Población y Vivienda.

Jovchelovitch, S. (2012). Narrative, memory and social representations: A conversation between history and social psychology. Integrative psychological and behavioral science, $46(4), 440-456$.

La Razón (2003, August 27, 2003). Potosí recupera sus antiguos colores. Retrieved from http:// www.bolivia.com/noticias/autonoticias/DetalleNoticia1556o.asp 
Lane, K. (2019). Potosi: the silver city that changed the world. Oakland, CA: University of California Press.

Macdonald, S. (2009). Difficult Heritage: Negotiating the Nazi Past in Nuremberg and Beyond. London: Routledge.

Macdonald, S. (2015). Is 'Difficult' Heritage Still 'Difficult'? Why Public Acknowledgement of Past Perpetration May No Longer Be So Unsettling to Collective Identities. Museum International, $67(1-4), 6-22$.

Machado Aráoz, H. (2014). Potosí, el origen. Genealogía de la minería contemporánea. Buenos Aires: Mardulce.

Mangan, J. E. (2005). Trading Roles. Gender, Ethnicity and the Urban Economy in Colonial Potosí. Durham and London: Duke University Press.

Maxwell, K. (1973). Conflicts and Conspiracies: Brazil and Portugal, 1750-1808. Cambridge: University Press.

Melucci, A. (1988). Getting involved: Identity and mobilization in social movements. International Social Movement Research, 1(26), 328-48.

Moh, C. (2014, October 2). Cerro Rico: Devil worship on the man-eating mountain. BBC News. Retrieved from: https://www.bbc.com/news/magazine-29448079

Nash, J. (1979). We eat the mines and the mines eat us: dependency and exploitation in Bolivian tin mines. New York: Columbia University Press.

Oieni, A. (2018, August 18). En el río Pilcomayo la contaminación enferma y mata. El Tribuno. Retrieved from: https://www.eltribuno.com/salta/nota/2018-8-25-20-4-o-enel-rio-pilcomayo-la-contaminacion-enferma-y-mata

Olick, J. F. (1998). Memory and the Nation: Continuities, Conflicts, and Transformations. Social Science History, 22(4), 377-387.

Olick, J. K. (2007). The Politics of Regret. On Collective Memory and Historical Responsability. New York, NY: Routledge. 
Omiste, M. (1992). Crónicas Potosinas. Segundo Tomo (4th ed.). Potosí: Distribuidora Cultural Sud.

Padden, R. C. (1975). Editor’s Introduction. In B. Arzáns de Orsúa y Vela (Ed.), Tales of Potosí (pp. xi-xxxvi). Providence: Brown University Press.

Pentland, J. B. (1975). Informe sobre Bolivia (1826). Potosí: Editorial Potosí.

Pollak, M. (1989). Memória, esquecimento, silêncio. Estudos históricos, 2(3), 3-15.

Prefeitura Municipal de Ouro Preto (2012). Dossiê de Risco Geológico: Programa Municipal de Análise Geotécnica e Diagnóstico de Risco de Ouro Preto. Ouro Preto, Brazil: Prefeitura Municipal de Ouro Preto.

Querajazu, L. (2010). Potosí Bicentenario. La Paz: Santillana.

Quesada, V. G. (1890). Crónicas Potosinas. Costumbres de la Edad Medieval HispanoAmericana. Tomo II. París: Biblioteca de la Europa y América.

Quijano, A. (2000). Colonialidad del Poder y Clasificación Social. Journal of World-Systems Research, $\operatorname{VI}(2), 342-386$

Quijano, A. (2005). Colonialidade do poder, eurocentrismo e América Latina. In E. Lander (Ed., A colonialidade do saber: eurocentrismo e ciências sociais. Perspectivas latino-americanas (pp. 227-278). Buenos Aires: Clacso.

Rezende, E., \& Cordeiro, V. V. (2019). De Mariana a Brumadinho: a efetividade da responsabilidade civil ambiental para a adoção das medidas de evacuação. Revista do Direito, $1(57)$, 160-181.

Rivera Cusicanqui, S. (2010). Violencias (re)encubiertas em Bolivia. La Paz: La Mirada Salvaje, Editorial Piedra Rota.

Robins, N. A. (2011). Mercury, Mining, and Empire: The Human and Ecological Cost of Colonial Silver Mining in the Andes. Bloomington and Indianapolis: Indiana University Press.

Scott, H. V. (2008). Colonialism, landscape and the subterranean. Geography Compass, 2(6), $1853-1869$. 
Svampa, M. (2013). "Consenso de los Commodities” y lenguajes de valoración en América Latina. Nueva Sociedad (244), 30-46.

Taussig, M. (1980). The devil and commodity fetishism in South America. Chapel Hill, NC: University of North Carolina Press.

Ulturgasheva, O. (2017). Ghosts of the Gulag in the Eveny World of the Dead. The Polar Journal, $7(1), 26-45$.

UNESCO (n.d.a). Historic Town of Ouro Preto. Retrieved from: https://whc.unesco.org/ en/list/124

UNESCO (n.d.b). City of Potosí. Retrieved from: https://whc.unesco.org/en/list/420

UNESCO (2014, June 12). City of Potosí (Plurinational State of Bolivia) added to List of World Heritage in Danger. Retrieved from: https://whc.unesco.org/en/news/1148/

UNESCO (1990). State of Conservation: Historic Town of Ouro Preto. Retrieved from: http:// whc.unesco.org/en/soc/1614, accessed May 7, 2015.

UNESCO (1993). State of Conservation: Historic Town of Ouro Preto. Retrieved from: http:// whc.unesco.org/en/soc/1752, accessed May 7, 2015.

UNESCO (2003). State of Conservation: Historic Town of Ouro Preto. Retrieved from: http://whc.unesco.org/en/soc/2779, accessed May 7, 2015.[C1]

UNESCO (2004). State of Conservation: Historic Town of Ouro Preto. Retrieved from: http://whc.unesco.org/en/soc/1504, accessed May 7, 2015.[C2]

Wade, P. (1997). Race and ethnicity in Latin America. London: Pluto Press.

Xavier, A. L. (2009). Tesouros, Fantasmas e Lendas de Ouro Preto. Ouro Preto: Rona Editora

Zavala Ayllón, W. (2012). Creación de la bandera potosina. El Potosí. Retrieved from http:// www.elpotosi.net/2012/1024/30.php

Zweig, S. (1942). Brazil, Land of the Future. London: Cassel and Company LTD. 